\title{
FORECASTING OF UNMET NEEDS PERCENTAGE IN EAST JAVA PROVINCE USING AUTOREGRESSIVE INTEGRATED MOVING AVERAGE (ARIMA) METHOD
}

\author{
Fery Styaningsih \\ Department of Biostatistics and Population, Faculty of Public Health, Universitas Airlangga, 60115 Surabaya, East Java, \\ Indonesia \\ Corresponding Author: Feri Styaningsih \\ E-mail: feri.yaningsih-2017@fkm.unair.ac.id
}

\begin{abstract}
ARIMA uses present and past values as the dependent variable. The accuracy of the ARIMA forecasting method results is good to be used to obtain short-term forecasts. Compared to other time series methods, the advantage of ARIMA method is that it can be used in the percentage of unmet needs data in East Java Province since ARIMA method does not require any specific data motives. Unmet need is a group of women who do not want to have any more children or want to minimize their pregnancy but refuse to use contraception to prevent pregnancy. This study aims to determine the percentage of unmet needs in East Java Province in the future. This study will analyze the value of forecasting and determine the best model for ARIMA. The data used is the monthly data of unmet needs percentage of East Java Province starting from January 2014 to April 2019 (64 data plots). The results showed that the percentage of the number of unmet needs in East Java Province can be predicted using ARIMA model $(12,1,0)$ without constant. The model is based on ARIMA $(12,1,0)$ diagnostic test without constant meeting all the test requirements. The results of forecasting held a MAPE value of $2.369 \%$ and MAE of $0.26 \%$. Based on MAPE and MAE, the model has a very good forecasting ability with a fairly small error value. Forecasting results indicated fluctuations in unmet needs data, where from December 2019 to February 2020 there was an increase in number of unmet needs in East Java Province. In the interim, starting in March 2020, the data needs in East Java Province tend to be constant at a higher position than the previous increase.
\end{abstract}

Keywords: ARIMA, time series, unmet need

\begin{abstract}
ABSTRAK
ARIMA memakai nilai pada masa sekarang dan pada masa lalu sebagai variabel dependen. Ketepatan hasil metode peramalan ARIMA baik dipergunakan agar memperoleh ramalan jangka pendek. Dibandingkan dengan cara time series yang lain, kelebihan metode ARIMA ini adalah cara ini bisa dipakai di data persentase unmet need di Provinsi Jawa Timur dikarenakan cara ARIMA ini tidak membutuhkan adanya motif data tertentu. Unmet need adalah sekelompok perempuan yang tidak ingin mempunyai anak lagi atau ingin menjarangkan kehamilannya tetapi tidak memakai alat kontrasepsi untuk mencegah kehamilannya. Penelitian ini bertujuan untuk mengetahui persentase unmet need di Provinsi Jawa Timur pada masa mendatang. Penelitian ini akan menganalisis nilai peramalan serta menentukan model terbaik untuk ARIMA. Data yang dipakai adalah data bulanan persentase unmet need Provinsi Jawa Timur mulai dari Januari 2014 sampai dengan April 2019 (64 plot data). Hasil menunjukkan persentase jumlah unmet need di Provinsi Jawa Timur dapat diramalkan menggunakan model ARIMA $(12,1,0)$ tanpa constant. Model tersebut berdasarkan uji diagnostik model ARIMA $(12,1,0)$ tanpa constant memenuhi syarat semua uji. Hasil dari peramalan memiliki nilai MAPE sebesar 2,369\% dan MAE sebesar 0,26\%. Berdasarkan MAPE dan MAE maka model tersebut mempunyai kemampuan meramal sangat baik dengan nilai kesalahan cukup kecil. Hasil peramalan menunjukkan fluktuasi data unmet need dimana pada bulan Desember 2019 sampai Februari 2020 akan terjadi peningkatan unmet need pada Provinsi Jawa Timur. Sedangkan mulai bulan Maret 2020 data unmet need pada Provinsi Jawa Timur cenderung konstan berada di posisi tinggi dari kenaikan sebelumnya.
\end{abstract}

Kata kunci: ARIMA, time series, unmet need 


\section{INTRODUCTION}

Percentage of unmet need in Indonesia is considerably still high. Based on data from the 2017 IDHS unmet need in Indonesia reached $10.6 \%$, which by $4.1 \%$ unmet need is minimizing the birth while the $6.5 \%$ is limiting the birth. This figure is converted to the number of fertile age couples which reaches 36 million, then around 4 million couples who need family planning but not yet served (National Board of Population and Family Planning, 2018).

Unmet need is Fertile Age Couple (FAC) who do not want children, want children with 2 years gap or more but do not use contraception (Resti, Barus and Anita, 2019). In basic terms, unmet need is defined as the needs of people who want to carry out a family planning program but their wish in carrying out the program is not fulfilled.

The reduction in unmet need is one of the five strategic objectives to be achieved by the East Java Province National Board of Population and Family Planning. A high unmet need has an impact on unwanted pregnancy and unsafe abortion. Unwanted pregnancy triggers women's health problems because there is a tendency to make an unsafe abortion. Mothers who become the unmet need for family planning are at risk of having an unwanted pregnancy, are most likely to commit an abortion. The National Board of Population and Family Planning seeks to reduce this unmet need because it is one of the factors causing $75 \%$ of maternal deaths in Indonesia (Rismawati, 2012).

Based on the 2017 IDHS, unmet need in East Java Province had reached $7.7 \%$ while based on routine statistics of East Java Province Representative National Board of Population and Family Planning data on unmet need in July 2019, it was $10.36 \%$ (East Java Province National Board of Population and Family Planning, 2019).

This study aims to determine the percentage of East Java Province Representative National Population and Family Planning Commission's unmet need in the future. The technique analysis that will be used is forecasting methods. Forecasting is the use of data from the past on a variable or a set of variables to estimate its value in the future. The forecasting method through the analysis of a variable that is estimated by a variable or time function is known as the time-series relationship method (Aziz, Sayuti and Mustakim, 2017).

The Time series model is a statistical method that models observational data taken in time, hourly, daily, weekly, monthly, semester, quarterly, or annually. Time series is an appropriate method used in forecasting data that has a pattern and is fairly consistent over a long period and results in continuous pattern data. Time series analysis is formulated in the assumption that time series consists of components including trends in trend $(\mathrm{T})$, cycle/pattern, season (S) pattern, random variation (R) (Arianti, 2015).

Time series in ARIMA method is used. This method in another reference is known as the Box-Jenkins time series. This method has a very good forecasting accuracy if used in shortterm forecasting, but the accuracy of ARIMA forecasting is not good if used in long-term forecasting. Forecasting using ARIMA, in the long run, will usually tend to be flat (horizontal/constant).

ARIMA or Autoregressive Integrated Moving Average model is a whole model that does not use independent variables informing the model for forecasting. ARIMA model, in other words, ignores the independent variables in making forecasting. ARIMA uses the past and present values of the dependent variable to produce accurate short-term forecasting. ARIMA is suitable if the results of observations of time series (time series) are related to each other (dependent) statistically (Arianti, 2015).

In this study, ARIMA method will be used to predict the percentage of unmet needs in East Java Province. ARIMA method is suitable because it will be used in short-term forecasting. Predicted data is expected to be material for policymaking and program planning in the future at the East Java Province Representative National Board of Population and Family Planning.

\section{METHODS}

The study was conducted with the initial stages of collecting data. Data collection techniques carried out using interviews, observations, and notes as well as studying the report document Analysis and Evaluation of the KKBPK Program East Java Province Representative National Board of Population and Family Planning from January to July 2019. Data collection was carried out during the 
apprenticeship activities at the East Java Province Representative National Board of Population and Family Planning. Data obtained from the Admin of East Java Province Representative National Board of Population and Family Planning. The data is published data so that it can be accessed by data users and intern students. Secondary data, in this case, is the monthly data percentage of unmet need in East Java Province from January 2014 to April 2019 (as many as 64 points plots).

The data is then analyzed using computer software, SPSS. The steps of analyzing data consist of three stages of ARIMA, which are identifying the model includes checking the identification of temporary models and the stationarity of the data. The second stage is parameter assessment and diagnostic testing including checking normal residual levels, white noise checks, and parameter significance checks. The third stage involves the application of forecasting and evaluation results (Kasanah, 2016).

ARIMA model used to predict parameter values is a model that meets the assumption requirements. These assumptions include normal residual assumptions and white noise. Besides that, the best model is chosen by comparing the larger $\mathrm{R}$ square value and the smaller error value. In this study, the error values used are MAPE and MAE.

\section{RESULT}

\section{Trend Percentage of Unmet Need in East Java Province}

Figure 1 shows that the unmet need percentage of East Java Province fluctuates. In
2014, from January to December, it tended to decrease, which was previously at a percentage of $11.77 \%$ in January and continued to decline until the end of 2014 by $10.48 \%$. Nevertheless, at the beginning of 2015, the percentage of unmet need increased again by $11.21 \%$ and there was a slow decline until the end of 2015 by $9.66 \%$.

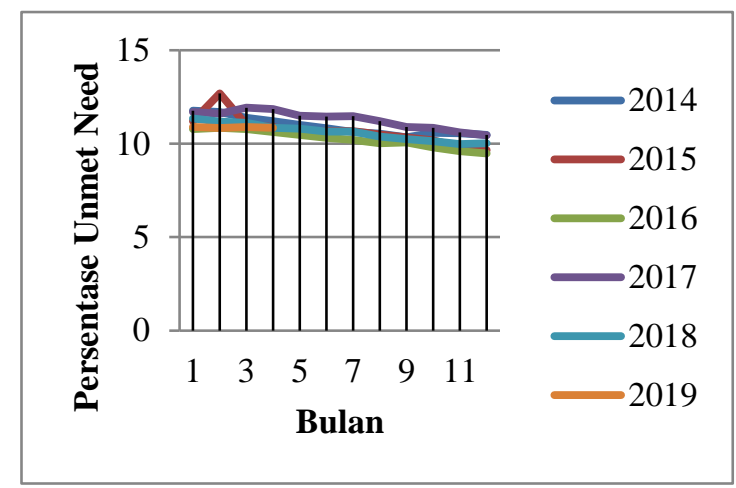

Figure 1. Plot Data Percentage of Unmet Need in East Java Province per Year

In 2016, the percentage of unmet needs in East Java Province showed a tendency to decrease slowly. At the beginning of 2016 at $10.79 \%$ and at the end of 2016, it became $9.48 \%$. Overall, there is a pattern of the high percentage of unmet needs at the beginning of the year and then decreases slowly at the end of the year.

\section{Examination of Unmet Need Stationary Data Percentage in East Java Province}

The first step in the Autoregressive Integrated Moving Average (ARIMA) is to check whether the data examined is stationary. Stationarity means that in a series or plot of

Table 1. Unmet Need in East Java Province as a Percentage in 2014-2019

\begin{tabular}{ccccccc}
\hline Month & $\mathbf{2 0 1 4}$ & $\mathbf{2 0 1 5}$ & $\mathbf{2 0 1 6}$ & $\mathbf{2 0 1 7}$ & $\mathbf{2 0 1 8}$ & $\mathbf{2 0 1 9}$ \\
\hline 1 & 11.77 & 11.21 & 10.79 & 11.69 & 11.35 & 10.9 \\
2 & 11.69 & 12.69 & 10.85 & 11.6 & 11.18 & 10.84 \\
3 & 11.39 & 11.01 & 10.78 & 11.93 & 11.11 & 10.89 \\
4 & 11.21 & 10.89 & 10.63 & 11.86 & 10.85 & 10.85 \\
5 & 11 & 10.56 & 10.47 & 11.49 & 10.81 & - \\
6 & 10.82 & 10.68 & 10.32 & 11.46 & 10.64 & - \\
7 & 10.63 & 10.68 & 10.21 & 11.48 & 10.65 & - \\
8 & 10.54 & 10.5 & 10.03 & 11.2 & 10.38 & - \\
9 & 10.34 & 10.34 & 10.07 & 10.9 & 10.24 & - \\
10 & 10.58 & 10.18 & 9.81 & 10.85 & 10.13 & - \\
11 & 10.55 & 9.83 & 9.6 & 10.6 & 9.98 & - \\
12 & 10.48 & 9.66 & 9.48 & 10.45 & 10.02 & - \\
\hline
\end{tabular}


data, there is no decline or growth in value. Horizontal values follow the time axis. Stationary data has fluctuations that are at a fixed average value and is independent of the time and variance of these fluctuations. Stationary data means it is always constant.

How to find out whether the data is stationary, is by looking at the overall data plot from month to month. The plot can be seen in Figure 2.

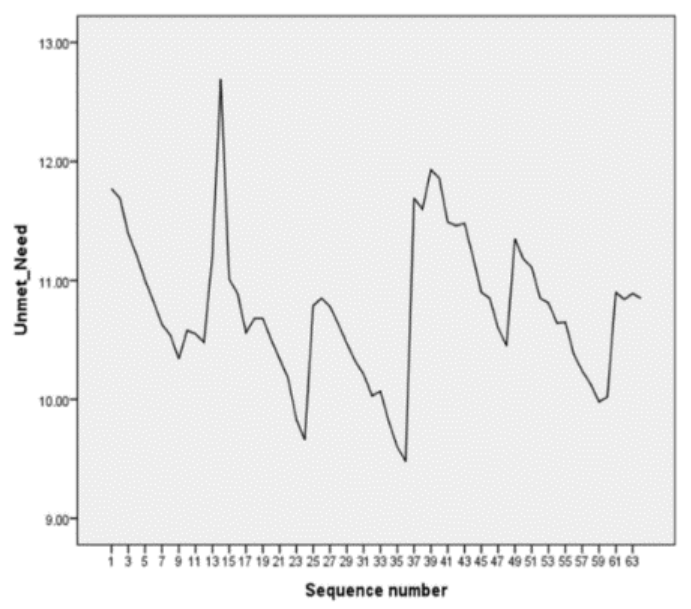

Figure 2. Data Plot Percentage of Overall Unmet Need

Figure 2 shows the spread of data based on the variance seen constant over time. The data plot did not include data variations that experienced a sharp increase or decrease. The variance value is 0.366 and it is also shown in figure 2 that the variance at each historical point is consistent with time. The percentage value of unmet need has been stationary invariance.

Based on Figure 2, data are not stationary in the mean. The mean value is 10.75 while the data are in the range of 9.48 to 12.69 . This shows data is not stationary in the mean. Data that is not stationary in the mean needs to go through differencing.

Differencing is calculating the difference from the value of observation or in other words calculating changes in the value of observation. The concept of difference is to subtract current observations (Yt) from previous observations, namely (Yt-1) (As'ad, Wibowo, and Sophia, 2017).

The percentage of unmet need data in East Province Java from January 2014 to April 2019 has been stationary variance and mean using first-order differencing. Unmet need percentage data plot in East Java Province shows that there is no growth and tends to be constant in means and variances. The data plot is constant from the starting point to the 64 th point. Therefore, the percentage of unmet need data in East Java Province is ready to be identified as a temporary model by looking at the ACF and PACF values of ARIMA model.

\section{Temporary Model Identification}

The second step is if the data is stationary at the mean and variance then a suitable ARIMA (p, d, q) model is determined. The percentage of unmet needs in East Java Province has been stationary after getting firstorder differencing. Consequently, the value $d$ is obtained 1 while ARIMA is (p, 1, q).

The next step is to determine the order of Autoregressive (p) and Moving Average (q) with ACF and PACF values on stationary time series data. The following is the ACF value obtained with d value 1 in the percentage data of unmet need in East Java Province from January 2014 to April 2019.

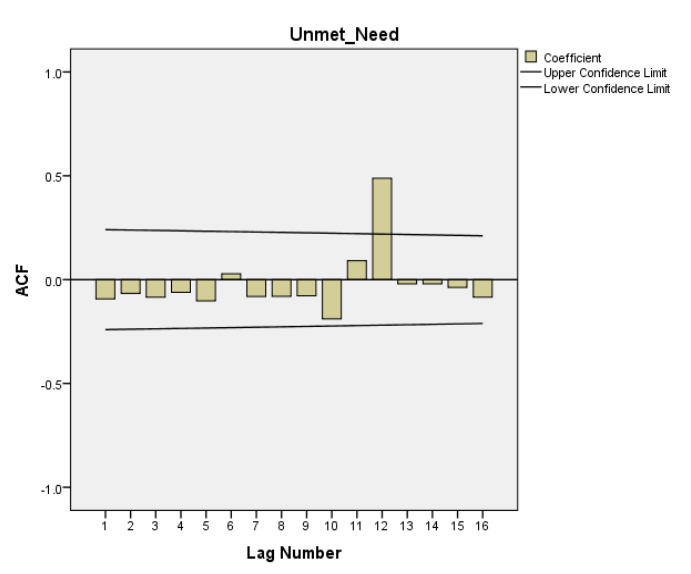

Figure 4. ACF plot of the First Order Differentiation

Based on the ACF plot in the data seen, the ACF is cut off at the 12th lag or called the cut off 12. And the current model assumption has a moving average (MA) aspect. As for the PACF plot, the percentage of unmet need data in East Java Province from January 2014 to April 2019 showed on figure 5 .

Based on the PACF plot, data cuts off is in lag 10 and lag 12. The model formed has an AR aspect. The PACF plot and ACF plot also have differencing in the first order, so that the temporary model for forecasting the unmet need percentage data in East Java Province from January 2014 to April 2019 is the ARIMA model $(12,1,0)$. 


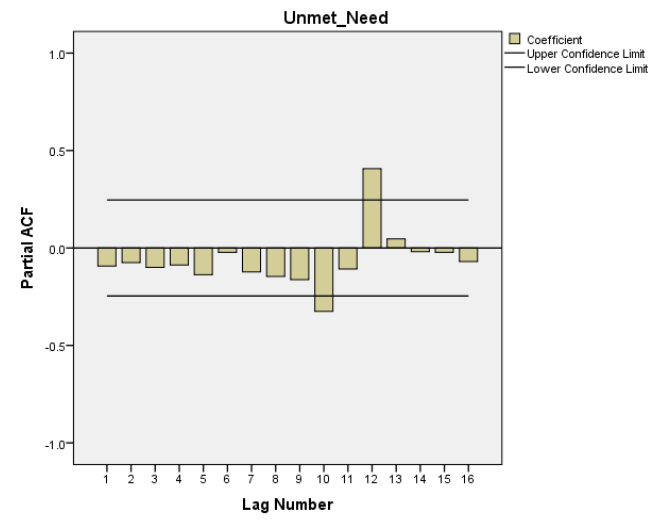

Figure 5. PACF Results of the First Order Differentiation Plot

\section{Model Parameter Estimation}

The next step after getting a temporary model is to find the value of the Autoregressive $\operatorname{coefficient}(\varphi)$ and the Moving Average coefficient $(\theta)$. The third step is determining the perfect and right comparison for the ARIMA model $(12,1,0)$.

The acquisition of the ARIMA model $(12,1,0)$ parameter projection is as follows: the AR 12 value has a coefficient of 0.368 in population parameters, while the standard error is 0.133 . Auto Regressive 12 produces a count of 2.76. The value of $t$ arithmetic at AR 12 is greater than the value of the $t$ table and therefore at the p-value obtained a significant value of less than 0.05 which is 0.008 .

The constant value has a coefficient of 0.010 in population parameters, while the standard error is 0.023 . A constant value produces a $t$ value of $0-0.45$. The magnitude of $t$ count at constant is less than the amount of $t$ table, therefore the p-value obtained is not significantly greater than 0.05 which is 0.65 .

The ARIMA model $(12,1,0)$ cannot be used because the constant value is not significant. The insignificant constant value needs to be removed so that this model can be used without a constant value.

The estimation results of the ARIMA model parameters (12.1.0) without a constant is that the AR 12 model has a coefficient value of 0.372 parameters. The ARIMA model $(12,1,0)$ without a constant has a standard error of 0.132 . The calculated $t$ value obtained in the model is 2.826 , the calculated $t$ value is greater than the table value so that the $p$-value has a significance value smaller than alpha $(0.05)$ which is 0.007 .

Based on table 3, the AR 12 value has $\mathrm{t}$ arithmetic $=2.826$. Because $t$ arithmetic $>\mathrm{T}$ table, so the AR parameter $=0.372$ is significant at $\alpha 5 \%$. The AR 12 value is significant without being constant, so the comparison of ARIMA $(12,1,0)$ is parameter $1 . \theta$ The ARIMA model $(12,1,0)$ without a constant meets the requirements estimation parameter.

\section{ARIMA Model Diagnostic Checks}

The ARIMA model's diagnostic checking is done by checking whether the model obtained at the projection level of the model parameters meets the requirements and the forecasting model can be used. The diagnostic examination of ARIMA model is the fourth step, which is to check normality, white noise in residuals, and test the model parameters' significance. A good model to be used in forecasting is a model that meets the third criteria of the test.

The first diagnostic test is the residual normality test in the ARIMA model diagnostic examination using Kolmogorov Smirnov statistical check. Checked hypotheses including normally distributed residuals ( $\mathrm{H} 0$-accepted). ARIMA residual normality test results $(12,1,0)$ without constant showed residuals have an average error value of -0.436 and a standard deviation of 0.38805 . Kolmogorov Smirnov's statistical test shows the p-value is $0.162>0.05$ and obtained $\mathrm{H} 0$-accepted, meaning that the normal residual is fulfilled.

The next diagnostic method for ARIMA model is the White Noise test. If the error value is random or random then a model is said to be good. The white noise that meets the diagnostic test requirements shows that it has no serial relationship (no autocorrelation). The residual does not have a specific random alias structure (mean $=0$, variant $=$ constant. White-noise tests can be seen in two ways. The first method uses the Box-Pierce Q Test statistics. The second method uses Ljung-Box. The Jenkins Box method can be called good if the residual has the nature of White-noise (H0-accepted) (Kasanah, 2016).

From the ARIMA white noise test (12.1.0) without a constant, it is found that the p-value is $0.715>\alpha(0.05)$ so that $\mathrm{H} 0$ is accepted, therefore the white noise residual in the ARIMA $(12,1.0)$ without a constant is qualified. The significant value of the AR 12 parameter is 0.007 <alpha (0.05) and $\mathrm{HO}$ is rejected which means that individually the parameter is different from zero, or it can be said that the forecasting parameter is feasible to use. The value of $\mathrm{R}^{2}$ was 
obtained at 0.586 . Analysis of the coefficient of determination $\mathrm{R}^{2}$ is used to find out how much the percentage of the independent variables describe the dependent variable. A good $\mathrm{R}^{2}$ value is above 0.5 since the $R^{2}$ value is between 0 to 1 . Overall, the ARIMA model $(12,1,0)$ without a constant has matched the results of diagnostic testing, the model is feasible to use.

\section{Use of the Best Model for Forecasting}

The next step is to use the best model. An appropriate model that matches the diagnostic test requirements is then used as a forecast. Forecasting that will be used for unmet need data in East Java Province from August 2019 to 2020 is the ARIMA equation model (12.1.0) without constants as follows:

(1-B) $(1)=\mu^{\prime}+(1 \mathrm{~B})-\phi_{1} \mathrm{~B} \mathrm{X}_{\mathrm{t}}-\theta_{1} \mathrm{e}_{\mathrm{t}}$ $(1-0,372)=X_{t} e_{t}$

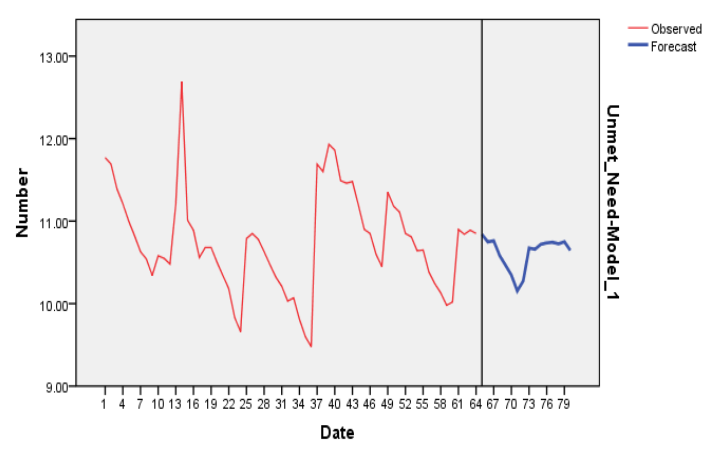

Figure 6. Unmet Need Data Plot for East Java Province and Forecasting

Figure 6 shows that unmet need forecasting in East Java Province was carried out for sixteen months from May 2019 to August 2020 with a $95 \%$ width interval. The results of the forecast area from the estimated original unmet need data in East Java Province from January 2014 to April 2019, as many as 64 points of historical value using the ARIMA $(12,1.0)$ without constant.

A value of 0.372 is a significant parameter on $\mathrm{AR} 12$, while the MA parameter is zero which is indicated by the symbol. The percentage of unmet need in the future can be calculated by first calculating the value of et (error value at time t) by entering the value of $\mathrm{Xt}$. The next step to predict is done by entering the value in the above equation. $(\theta)$

These results are evaluated using the accuracy measures, i.e. Mean Absolute Percentage Error (MAPE) and Mean Absolute
Error (MAE). The way to calculate MAPE is by calculating the absolute error of each period divided by the real observation value in that period. The absolute error is then averaged so that the MAPE value can be determined. This approach is useful when the size of the forecast variable is important in evaluating the accuracy of the forecast. MAPE determines how big the forecast error is compared to the real value (Margi and Pendawa, 2015).

Based on the ARIMA model $(12,1,0)$ without a constant, the MAPE value was $2,369 \%$. A method is said to have the ability to forecast well and accurately if it has a MAPE value $<10 \%$. Models that have a MAPE value less than $20 \%$ have good forecasting abilities (Pakaja, Naba, and Purwanto, 2012). The MAE value shows a value of $0.26 \%$ which indicates that if forecasting is used for the next 12 periods, then there is an error of $0.26 \%$. MAPE and MAE values that are large, indicate less accurate forecasting results.

\section{DISCUSSION}

\section{General Description of Unmet Need Percentage in East Java Province}

The number of unmet needs in East Java Province fluctuates every month. From 2014 to 2019 the percentage of unmet need was in the range of a minimum value of $9.48 \%$ and a maximum value of $12.69 \%$. If the average percentage of unmet needs over a period of five years, the value is $10.76 \%$. The East Java Province National Board of Population and Family Planning Strategic Plan 2015-2019 was targeting to decrease the unmet need for 10.1 in 2014 to 10 in 2019 . This value has not yet reached the target.

The high percentage of unmet needs for family planning shows the low prevalence of contraception that triggers high birth rates and can result in a population explosion. The high number of unmet needs also influences the number of children born and the close birth gap between children. Unmet need figures indirectly pose a great risk to maternal and infant mortality. An unwanted pregnancy can also trigger an abortion which also increases the risk of maternal death (Fadhila, Widoyo and Elytha, 2016).

Women of fertile age have a great chance of getting pregnant if they do not use contraception. Pregnancy can make women of 
fertile age experience complications during pregnancy, excessive childbirth, the onset of disease during pregnancy, abortion due to unwanted pregnancy, close gap between children, difficult labor, and severe puerperium.

Unmet need data in East Java Province in July 2019 showed that the highest unmet need in Pamekasan by $14.67 \%$. Unmet needs data in Surabaya is still high at $13.64 \%$. Couples of fertile age who are not family planning participants, do not want children and want to postpone pregnancy but do not get family planning services in Surabaya are as many as 69,548. Other regions that the percentage of unmet needs is still high are Ponorogo by $13.73 \%$, Trenggalek by $13.72 \%$, and Gresik by $13.82 \%$ (East Java Province National Board of Population and Family Planning, 2019).

Regencies with the lowest five unmet need achievements in East Java Province were recorded in July 2019, including Madiun (city), Bojonegoro (district), Probolinggo (district), Ngawi (district), and Lamongan (district). Madiun has the lowest percentage of unmet needs in East Java Province, which is $4.61 \%$. Bojonegoro is by $5.75 \%$, Probolinggo is by $5.77 \%$, while Ngawi is by $6.05 \%$ and Lamongan is by $6.06 \%$ (East Java Province National Board of Population and Family Planning, 2019).

Data on family planning counselors in East Java Province in 2019 revealed that the distribution of family planning counselors was still uneven. The number of family planning counselors still partially does not adjust to the total number of fertile age couples targeted by KB. Surabaya has as many as 509,933 fertile age couples and the number of unmet needs is classified as high while there are only 21 family planning counselors. Probolinggo which the number of fertile age couples is 277,132 and its unmet needs is low by $5.77 \%$ has 100 family planning counselors. The distribution of family planning counselors in East Java also needs to be reviewed to be a strategy in the effort to reduce the unmet needs in East Java (East Java Province National Board of Population and Family Planning, 2019).

Health facility staffs play an important role in providing quality family planning services. They are responsible for providing information about available contraception choices and explaining to prospective users of contraception related to the ability of health facilities to serve a variety of contraception choices (Ekoriano, 2018).

\section{Forecasting Unmet Need Percentage in East Java Province}

Forecasting is used to predict something that likely to occur in the future so that the right action can be taken. (Astutik, Sukestiyarno, and Hendikawati, 2018). One of the East Java Province Representative National Board of Population and Family Planning programs in the strategic plan is to reduce the number of unmet needs. Forecasting results obtained indicate the number of unmet needs in East is expected to decrease further. Figure 6 shows that the trend of unmet needs for five years fluctuates with a downward trend and there is a constant increase.

Forecasting models are used to predict the percentage of unmet needs in the future using the ARIMA model $(12,1,0)$ without constant. This indicates the model used is AR (AutoRegressive) 12 with first-order differencing. First-order differencing means that analyzing data to obtain forecasting models using unmet need data differences from month to month. In conclusion, the data used to predict is the result of subtraction data between the current observations, namely the percentage of unmet need for February and the percentage of unmet need for March and so on.

Forecasting results (blue line) show the fluctuation of unmet need data where in December 2019 until February 2020 there will be an increase in unmet need in East Java Province. Whereas starting in March 2020 the data needs in East Java Province tend to be constant after the previous increase.

Rismawati (2012) concluded that unmet need is seen in the fertility transition phase in a country. Indicators that led to the decline in unmet need including changes in reproductive behavior and contraception prevalence. According to Rismawati (2012), an effective way in efforts to succeed in the family planning program is through health education. This education has the aim to change behavior directly or indirectly so that it becomes better by following the recommendations and views expressed. The following supporting factors are needed for the success of the family planning program including the material, media, methods, place, and time of the implementation of health education.

Improving family planning services through counseling that refers to the wishes of the client as well as various choices of family 
planning methods, and the availability of services that can be accessed easily for the community in need are the most important factors in supporting the reduction in the number of maternal deaths. Unmet needs and family planning failures are the biggest indicators of the cause of unwanted pregnancy. In this case, the participation of health workers to deliver knowledge to change people's behavior is an obligation. Improving service quality is also an efficient way to reduce the prevalence of unmet need for family planning (Rismawati, 2012).

According to Kartika (2014) based on the results of her research, it can be seen that the majority of respondents who are unmet need do not support family planning. Another factor influencing unmet need is access to family planning services, which include social, type, and quality health services, as well as information that affects the occurrence of unmet need for family planning.

According to Sarlis (2019), there is a relationship between husband support for unmet needs. The husband's support mentioned is the support of the husband to his wife, both moral and material support for the selection of appropriate and comfortable contraception. Support from family members can enable families to carry out their respective functions properly. A husband as the part of the family should provide support and attention to circumstances and needs of his wife's health

East Java Province Representative National Board of Population and Family Planning needs to formulate specific strategies to anticipate an increase in unmet needs at a time based on prediction results will begin to increase. Anticipations that can be made including programs related to reducing the number of unmet needs, such as family planning achievements and access to family planning services, which should be intensified in the first trimester of the coming fiscal year.

\section{The Importance of Forecasting Percentage of Unmet Needs in East Java Province from 2019 to 2020}

Indonesia supports the strategy of the UNFPA (United Nations Population Fund), sn institution under the authority of the UN General Assembly. The target is "3 Zero" which is the global target: 1) zero maternal and infant's deaths; 2) zero unmet need in Family Planning, and 3) zero domestic violence against women. The strategy is targeted to be achieved in 2030 (UNFPA, 2018). Therefore, it is important to do unmet needs forecasting to find out how many unmet needs predictions in the future.

The results of the forecast are used for advice to the National Board of Population and Family Planning Representatives of East Java to be continued to make program policies and plan resource requirements for anticipatory measures. This prediction can be used as a step to formulate a new strategy if the previous method does not make significant results. One step that can be done is the distribution of family planning counselors in East Java by considering the number of fertile age women targets.

\section{CONCLUSIONS AND SUGGESTIONS}

\section{Conclusion}

ARIMA that can be used to forecast the percentage of unmet needs in East Java is ARIMA $(12,1,0)$ without constant with the following equation:

$$
\begin{gathered}
\left(\phi_{1} B\right)(1 \mathrm{~B})=\mu^{\prime}+(1 \mathrm{~B})-\theta_{1} \mathrm{x}_{\mathrm{t}}-\theta_{1} \mathrm{e}_{\mathrm{t}} \\
(1-0,372)=\mathrm{x}_{\mathrm{t}} \mathrm{e}_{\mathrm{t}}
\end{gathered}
$$

The ARIMA model above has all the assumptions of diagnostic tests, making it possible to use. The results of the percentage of unmet needs conclude that the graph decreases compared to the previous year's actual data values. Forecasting results obtained MAPE $=$ $2.369 \%$ and $\mathrm{MAE}=0.26 \%$. Based on MAPE, the model has a very good forecasting ability while the MAE value also indicates the error value is quite small.

Based on the results of forecasting using the ARIMA model $(12,1,0)$ without a constant, it is obtained that the estimated unmet needs for East Java will tend to decrease. However, it is necessary to beware for an increase in the number of unmet needs in East Java from December 2019 to February 2020.

\section{Suggestion}

Input to National Board of Population and Family Planning Representatives of East Java Province is unmet need relates to unwanted pregnancy and can increase the risk of maternal mortality. Therefore, from reducing the unmet need, it indirectly increases the factor in 
reducing maternal mortality. The distribution of family planning counselors in East Java also needs to be reviewed following the number of fertile age couples and consider the indicator of unmet needs as one of the strategies to reduce the unmet needs in East Java.

\section{REFERENCES}

Arianti, C., 2015. Prediksi Jumlah Pencapaian KB Baru IUD di Kabupaten Jombang dengan Metode Autoregressive Integrated Moving Average (ARIMA). Thesis. Universitas Airlangga.

As'ad, M., Wibowo, S.S., and Sophia, E., 2017. Peramalan Jumlah Mahasiswa Baru dengan Model Autoregressive Integrated Moving Average (ARIMA). JIMP - Jurnal Informatika Merdeka Pasuruan, 2 (3), pp.20-33.

Astutik, S.R., Sukestiyarno, and Hendikawati, P., 2018. Peramalan Inflasi di Demak Menggunakan Metode ARIMA Berbantuan Software R dan Minitab. Jurnal Universitas Negeri Semarang. Prisma I: pp.745-754.

Aziz, S., Sayuti, A., and Mustakim, 2017. Penerapan Metode ARIMA untuk Peramalan Pengunjung Perpustakaan UIN Suska Riau. Seminar Nasional Teknologi Informasi Komunikasi dan Industri, 2018 (SNTIKI 9), pp.186-193.

East Java Province National Board of Population and Family Planning, 2019. Hasil Evaluasi dan Analisis Program $K K B P K$. Surabaya.

Ekoriano, M., and Novita, F., 2018. Dinamika Pemakaian Kontrasepsi Modern di Indonesia (Analisis Data Susenas 2015). Jurnal Kependudukan Indonesia, 13 (1), pp. 27-38.

Fadhila, N.H, Widoyo, R., and Elytha, F., 2016. Unmed Need Keluarga Berencana pada Pasangan Usia Subur di Kecamatan Padang Barat Tahun 2015. Jurnal Kesehatan Masyarakat Andalas, 10 (2), pp.151-156.
Kartika, W.D.D., 2014. Pengaruh Faktor Unmet Need Keluarga Berencana. Jurnal Biometrika dan Kependudukan, 4 (1), pp. 70-75.

Kasanah, L.N., 2016. Pengaplikasian Autoregressive Integrated Moving Average (ARIMA) Guna Memprediksi DBD (Demam Berdarah Dengue) pada Puskesmas Mulyorejo. Jurnal Biometrika dan Kependudukan, 5 (2), pp.177-186.

Margi, K., and Pendawa, S., 2015. Analisa dan Penerapan Metode Single Exponential Smoothing untuk Prediksi Penjualan pada Periode Tertentu (Studi Kasus: PT. Media Cemara Kreasi). In: Prosiding SNATIF Ke2. Kudus: Fakultas Teknik-Universitas Muara Kudus, pp.259-266.

National Board of Population and Family Planning, 2018. Survei Demografi dan Kesehatan Indonesia 2017. Jakarta.

Pakaja, F., Naba, A., and Purwanto, 2012. Peramalan Penjualan Mobil Menggunakan Jaringan Syaraf Tiruan dan Certainty Factor. Jurnal EECCIS, 6 (1), pp. 23-28.

Resti, S. N., Barus, E., and Anita, S., 2019. Analisis Unmet Need KB pada Wanita Pasangan Usia Subur (PUS) di Wilayah Pesisir Pantai Desa Bagan Kecamatan Percut Sei Tuan Kabupaten Deli Serdang Tahun 2019. Midwifery Journal, 4 (2), pp. 71-73

Rismawati, S., 2012. Unmet Need: Tantangan Program Keluarga Berencana dalam Menghadapi Ledakan Penduduk Tahun 2030. Thesis. Universitas Padjadjaran.

Sarlis, N., 2019. Faktor yang Berhubungan dengan Unmet Need pada Ibu Non Akseptor Tahun 2018. Jurnal Endurance: Kajian Ilmiah Problema Kesehatan, 4 (1), pp.184-193.

UNFPA, 2018. New Year, New Beginnings. [online] United Nations Population Fund. Available at: <https://www.unfpa.org/press/new-yearnew-beginnings> [Accessed 3 Dec. 2019]. 